\title{
Lalibela: Spiritual Genealogy beyond Epistemic Violence in Ethiopia
}

\author{
Yirga Gelaw Woldeyes
}

Centre for Human Rights Education, Curtin University, Bentley 6102, Australia; yirga.woldeyes@curtin.edu.au

Received: 31 December 2018; Accepted: 26 November 2019; Published: 2 December 2019

\begin{abstract}
The rock hewn churches of Lalibela have special significance in the formation of Ethiopia's consciousness as a sacred land of God's covenant. Numerous local stories express the sanctity of Lalibela as a Heavenly Jerusalem on earth and the faithful use holy soil from the churches to cure the sick. Every year, thousands of Tewahido believers travel to receive blessings. Local scholars who studied decades in the indigenous education system serve as intermediaries between the sanctity of the place and the people, and transmit their knowledge to the younger generation. This paper traces this spiritual genealogy to the creation story in the Kebra Nagast regarding the Ark of the Covenant (Tabot) and relates it to Lalibela's famous churches. It demonstrates the existence of enduring spiritual genealogy that considers place as alive and powerful. The paper also reflects on how the loss of indigenous sources of knowledges, particularly through the stealing or taking of manuscripts by foreign collectors, and the rise of a Eurocentric interpretation of the history of Lalibela challenges this millennial spiritual tradition. It argues that this has resulted in epistemic violence, the practice of interpreting local knowledge with a foreign lens in a way that reinforces colonial Eurocentric views that are then internalised within Africans themselves. Despite such challenges, it shows how the genealogy continues through the very identity and practice of local communities and individuals.
\end{abstract}

Keywords: Lalibela; Ethiopia; heritage; conservation; indigenous knowledge; tourism

\section{Introduction}

In Ethiopia, Lalibela's ancient rock-hewn churches are connected by a series of underground tunnels and caves. I spent my childhood in the late 1970s and 1980s running through this labyrinth. One day, while I was playing with my friends in the tunnels, a man appeared from one of the small caves. He had very long hair, large prayer beads made of wood, and shabby clothes. He was one of the many hermits who lived, often in complete silence, in the church compound. My friends and I froze as he approached us. He bent down to our level and pointed towards the church, asking what we saw. We replied, "We see the church". He asked if we were able to see anything else. We replied no. Then he said:

You may not see them, but there are angels right there. They worked with Lalibela when he built the churches. They don't die or go hungry. They live here because this is heaven. Their large wings are stretching towards the sky. They hover surrounding the churches; they sing. They are everywhere. If you come during Kidassie (Ethiopian liturgical Mass), you would feel them falling before the Tabot (Ark of the Covenant). They're guardians of this entire area. They do not like much noise. They want you to be like them. To come here, to listen, and gain blessings.

The hermit's story changed how my friends and I related to Lalibela, which was created as a New Jerusalem, a heaven on earth, during King Lalibela's time (1181-1221 AD). During his reign, eleven 
churches were carved out of the mountains at Roha. The surrounding mountains, gorges and other

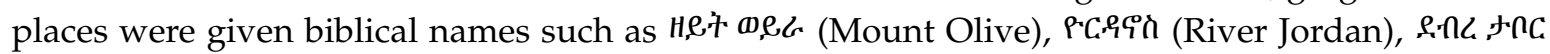

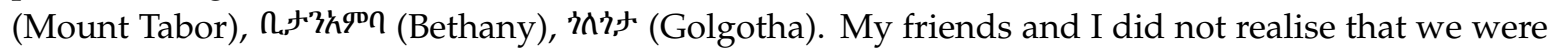
living in a city that was considered one of the holiest places in the entire country. But from that moment, we began to pay attention. Whenever we came close to the churches, we knew we were walking with the hordes of heaven. See Figures 1-3.

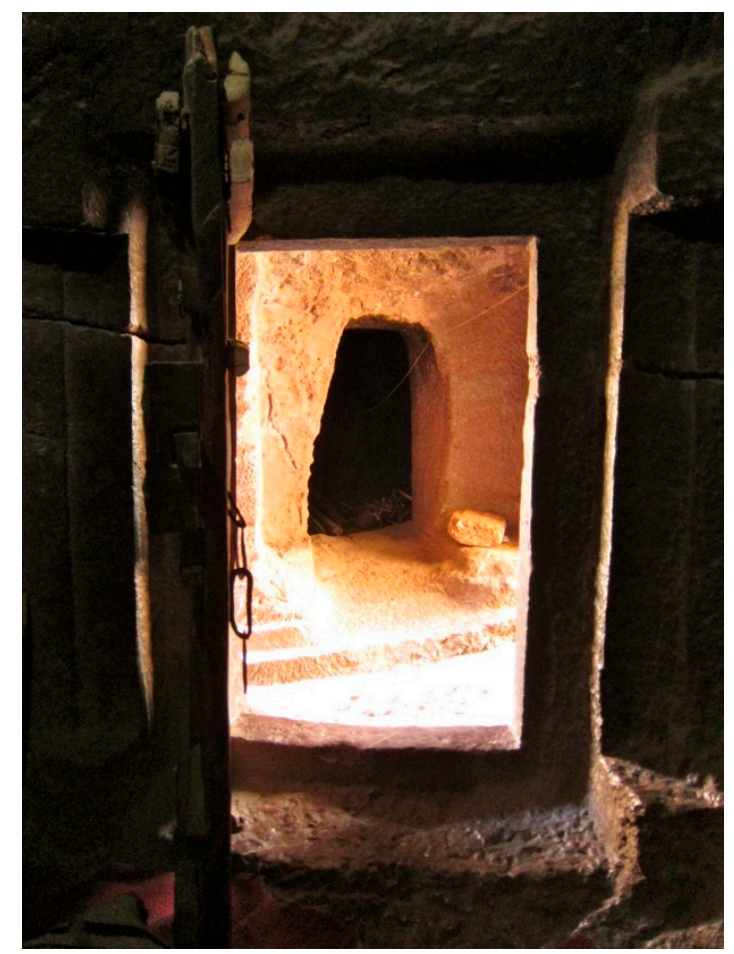

Figure 1. A passage way through Bete Mariam (House of Mary), one of the rock-hewn churches of Lalibela. Photograph by Martijn Munneke, courtesy of Creative Commons Attribution.

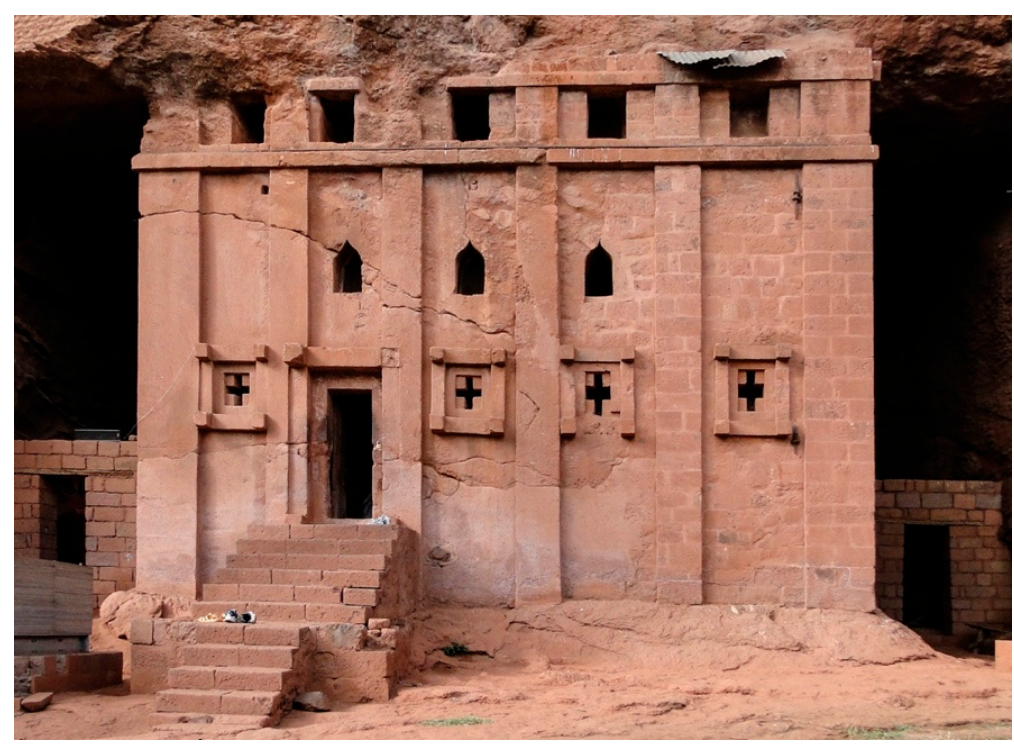

Figure 2. Shoes are left on the steps of Bete Abba Libanos (House of Abbot Libanos). (Photograph by Bernard Gagnon, courtesy of the GNU Free Documentation License). 


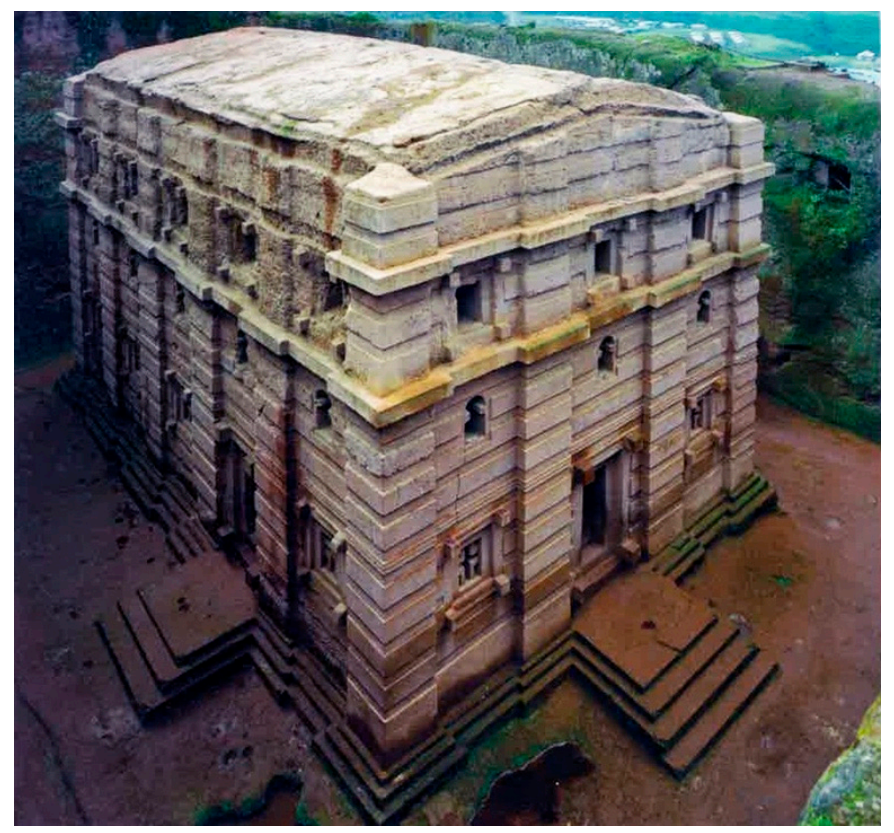

Figure 3. The House of Amanuel has underground tunnels, stories and detailed structures. It is regarded as the most beautiful of all the churches. It is also the most affected by harmful conservation methods. (Photograph by Giovanni Lami 2007).

As a child, my first language was Amharic. I learned parts of Ge'ez, the ancient holy language of Ethiopia when I attended the traditional school system, and learned English through the western school system in Ethiopia, which is in English from high school onwards. I also picked up Ge'ez attending Sunday school and from listening to the stories of the hermits, monks, nuns, priests and spiritual scholars who lived in communion with the church and our community. At the age of 16, I started to attend Kidassie on the monthly commemoration of the Tabots in each of the Lalibela churches. Tabot is understood as "q.S. $\rho$, or "dwelling place", and they are foundational to Orthodox Tewahido Christianity. A church is not recognised as a church unless it has a Tabot—a replica of the Biblical "Ark of the Covenant"-at its sanctum sanctorum (the inner centre). Every replica of the Ark of the Covenant is as sacred as the original brought from Israel. During Kidassie, heavenly angels are said to fall on the floor of the church whenever the priest places the Eucharist on the Tabot.

Other times, my friends and I gathered in the compound of Bete Medhanialem and in the caves of Amanuel and Bete Mariam (See Figure 4) churches to study scripture with the monk-scholar Aba Zekarias. He was referred to as Arat Ayina, Four Eyed-someone with the ability to see the past as well as the future. Arat Ayina knew infinite stories, verses and fables. He read from the ancient books written in Ge'ez, and used Amharic to educate us in the 81 books of the Ethiopian Bible. He said Ge'ez was the language Adam and Eve spoke in the Garden of Eden. After the Great Flood, Noah divided the world for his children and Ham (Kam) brought the language to Ethiopia. All other languages were created when Egziabher (God) destroyed the Tower of Babel 551 years after the Great Flood ${ }^{1}$.

Aba Zekarias explained that in Lalibela, the healing power of Egziabher is mixed with the soil of the rock churches. Especially in the House of Golegota-Selassie, where King Lalibela is buried, priests give red soil from the sanctum sanctorum as medicine for the sick. People eat a pinch of the holy soil or paint the sick part of their body with it. We also learned ancient songs from the melodist Riese Debir Gebra Maskal Amagnu. We lived with angels and God. The rocks we walked on in and around the churches were holier than us. Every time we came, we bowed and kissed them

1 A traditional scholar (Aleka) Asres Yenesewu (1959a, 1959b) has published two important works in Amharic that elaborate on the genealogy of the Ge'ez language and related Ethiopian themes. 


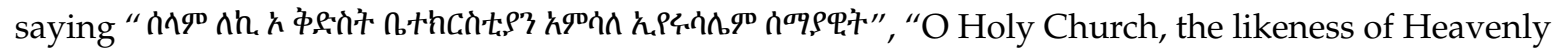
Jerusalem, may peace be upon you".

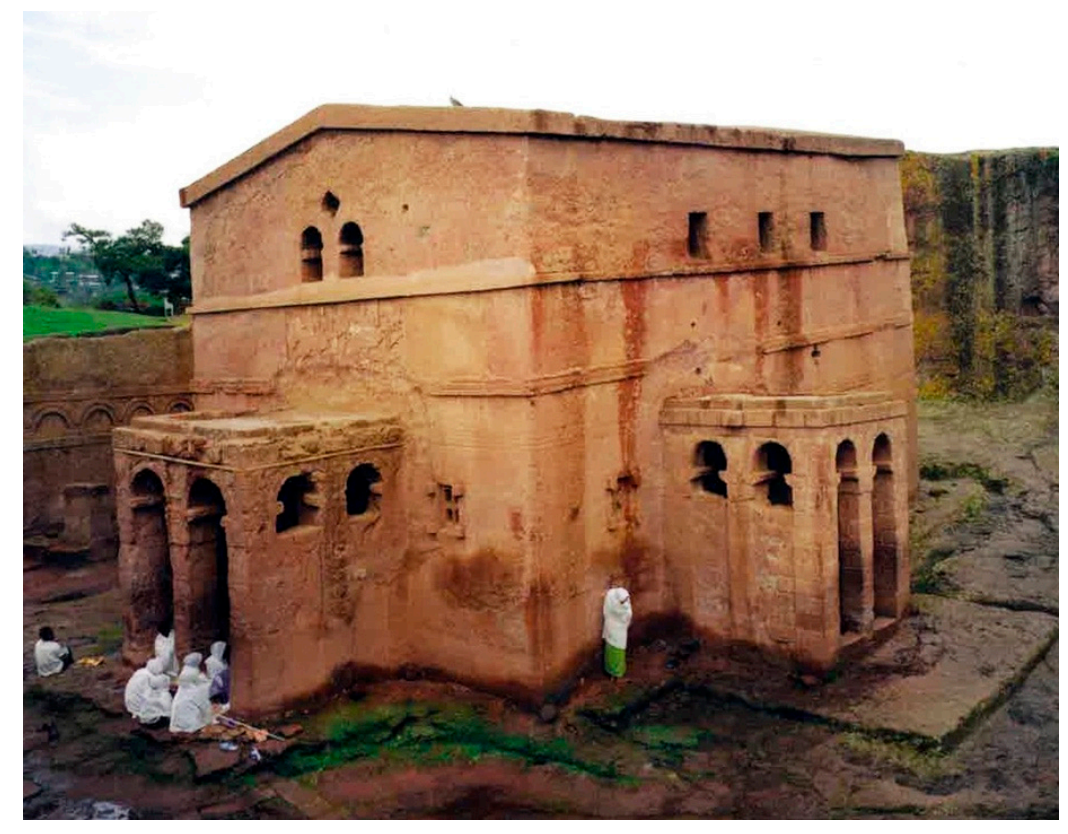

Figure 4. Bete Mariam (House of Mary) was the first church to be built by King Lalibela. It sits in the middle of four churches: In the north Bete Medhanialem-the largest in size, in the south Bete Golegota-Selassie, in the east Bete Denagil, and in the west Bete Meskel. Local residents pray in the church compound. (Photograph by Giovanni Lami 2007).

Our experiences growing up are by no way unique to our city, but speak to one of the many ways that people in Lalibela develop a deep spiritual relationship to the churches and the town itself. Like other indigenous perspectives, rather than being conceived as a tabula rasa, waiting to be authored or acted upon by human beings, the traditional beliefs of Ethiopians understand place to have agency that can impose demands on human beings (Deloria 2003; Basso 1996; Smith 2005; Clement 2017). As Vanessa Watts has written, "land is alive and thinking" (Watts 2013, p. 21). Residents of Lalibela are taught that the world is imbued with values, knowledge and significance. Like other African philosophical traditions such as Ubuntu, which view life as a sacred connection among the human, the non-human and the spirit world (Mbiti 1969; Jahn 1961), Lalibela's churches are places embodied with spiritual meaning and identity. The Ge'ez saying " oDh' humans and humans bless place) indicates a view of place suffused with values, personalities and actions that complicates the dualism between humans and the environment.

The spiritual history and place-based perspectives of Lalibela remain important among believers and local people. Modern Ethiopian history, written by European and western-trained local scholars, however, misinterprets or disregards how people in Lalibela interpret and act on this spiritual history. As Edward Said's most influential work Orientalism shows, Europe has a long history of narrating the history of the Other (Said 1978). It is also the major consumer of its own narration and markets these texts around the world-to the Others themselves. In this colonial framework, Africa is reproduced with images that emphasise inherent defect, suffering, and absence, which help render the violence of Western knowledge invisible (Ndlovu-Gatsheni 2018; Wa Thiong'o 1994). In Ethiopia, there are many factors that contribute to Orientalism, including the loss of local manuscripts, the acceptance of Western historiography as a true account of the history of the spirituality of the country, and the rise of native colonialism - a process whereby a country colonises itself using Western ideas and institutions (Woldeyes 2017). 
The political autonomy of Ethiopia, which traced its beginnings to the Ark of the Covenant, were maintained until 1974, when a Marxist-Leninist revolution interrupted the political role of the Tabot by executing the last Emperor of the Solomonic Dynasty, Haile Selassie I. During this time, the political elites used the cultural, intellectual and institutional capital of the West to develop native colonialism over their own people (Woldeyes 2017). English was introduced as the language of education, knowledge production, and development as a method of "catching up" with the West (Kebede 2008, p. 56). Native colonialism decentres traditional knowledges and practices. As we will see, some Orientalist views have been internalised by Ethiopians, while others hold onto their own cultural and historical frameworks. Just as the people of Lalibela struggle to keep their ties to their church, this article attempts to reclaim these traditional narratives and practices.

\section{God and Place: The Genealogy of Ethiopian Christianity}

One of the foundational texts of Ethiopian Christianity is the ancient text Kebra Nagast (Glory of Kings), which is written in Ge'ez. The earliest known copy of the book dates between the fourth and sixth century AD, although a copy from the 13th century is the most well-referenced. The Kebra Nagast begins with the creation of the heavens and earth, and leads to Ethiopia being transformed into the New Jerusalem with the arrival of the Ark of the Covenant.

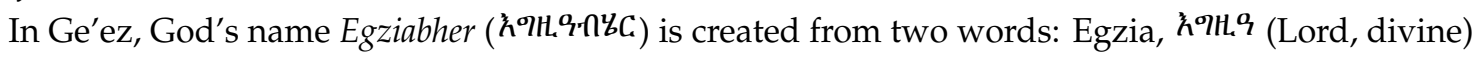

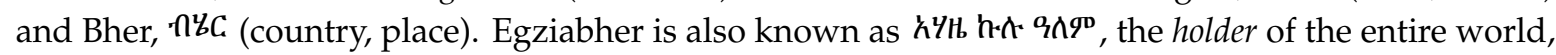

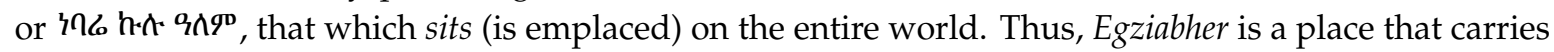
all places; it is also a divine that exists in all places. According to the Kebra Nagast, Egziabher first created a place for Himself that was known as Tabernacle of the Covenant. This moveable sanctuary was His first dwelling place:

Behold now, we understand clearly that before every created thing, even the angels, and before the heavens and the earth, and before the pillars of heaven, and the abysses of the sea, He created the Tabernacle of the Covenant, and this which is in heaven goeth upon the earth. (Kebra Nagast 1932, p. 7)

According to the Kebra Nagast, the Tabernacle of the Covenant, ordained with precious objects that look like jasper, topaz, hyacinthine stones, and crystals, holds intangible, divine power:

It catches the eye by force, and it astonishes the mind and stupefies it with wonder ....

It is a spiritual thing, it is full of compassion; it is a heavenly thing and is full of light; it is a thing of freedom and a habitation of the Godhead, Whose habitation is in heaven, and Whose place of movement is on earth, and it dwelleth with men and with the angels, a city of salvation of men, and for the Holy Spirit a habitation. (Kebra Nagast 1932, p. 12)

Egziabher brought it down to the earth, and "permitted Moses to make the likeness of it" (Kebra Nagast 1932, p. 12). Moses made an Ark, a box, from "a wood that cannot be eaten by worms, and overlay it with pure gold" (1932, p. 12). Following the instruction of Egziabher, he placed the heavenly Covenant inside the Ark. He also constructed a tent on Mount Sinai to place the Ark of the Covenant. From there, Egziabher spoke regularly with his chosen ones to bless them, and to lead them to salvation. From the time of Moses to King Solomon, the Ark of the Covenant became the sign and the seal for the salvation of Israel. Solomon built the Temple in Jerusalem for the Ark of the Covenant, but later it vanished from the history of the Jewish books. Despite lack of international agreement regarding its last whereabouts, no country has a fuller account of written, oral, and spiritual evidence than Ethiopia to show that they possess the Ark of the Covenant (Isaac 2013).

It is in the Kebra Nagast that the story of the Ark of the Covenant continues beyond Israel. In around 950 BC, the Ethiopian Queen Makda, also known as the Queen of Sheba, is said to have heard about the wisdoms of Solomon and decided to visit him. They conceived a child, and she returned to Ethiopia. 
Their baby, Menelik, was born and started to grow without his father. Upon his insistence to know him, Queen Makba told Menelik about Solomon and he travelled to Jerusalem to meet him. According to the Kebra Nagast, Solomon asked Menelik to succeed him, but he declined the offer out of love for his people and the land of Ethiopia. In response, Solomon gathered his nobles, princes, and priests and ordered them to send their first-born sons "along with 1000 chosen people from each of the Twelve Tribes of Israel" to serve Menelik in Africa (Isaac 2013, p. 50).

In the Kebra Nagast, the children of the dignitaries secretly decide to take the Ark of the Covenant for their own protection in the new land. The text emphasises that the whole plan was Egziabher's wish, stating that He loved the land of Ethiopia more than Israel for He knew they, unlike the Israelis, would accept His son Jesus. Upon its arrival in Ethiopia, the Ark of the Covenant was placed at the Empire's capital in Axum. With the coming of the Ark of the Covenant, Ethiopia became "The New Jerusalem" that inhabited Egziabher's glory. The Kebra Nagast declares:

The chosen one of the Lord are the people of Ethiopia. For there is the habitation of God, the Heavenly Zion the Tabernacle of His Law and the Tabernacle of His Covenant, which he has made into a mercy-seat. (1932, p. 144)

The long-term ties between Israel and Ethiopia are thus political, spiritual, and genealogical. Through the birth of King Solomon and Queen Makda's child, Menelik, the lands were connected, and these ties became divine with the arrival of the Ark of the Covenant in Axum. It is no surprise, then, that an early dialogue with Christian disciples developed in the two regions. The Ethiopian church teaches that Jesus's disciple, Matthew, preached Christianity in Axum. It is also believed that Judaic Ethiopians who travelled to Jerusalem for the Passover attended the day of the Pentecost when Peter preached to the crowd (Acts 2). They converted to Christianity and upon their return spread the faith in Ethiopia.

In Acts 8, from 26-40, the Bible tells how an Ethiopian eunuch at Queen Candice's court in Axum read the Book of Isaias on his way to Jerusalem. He was approached by Philip, who told him about Christ and baptised him. When he returned, the eunuch began baptising people, which led to the blend of traditional, Judaic, and Christian teachings in Ethiopia. The translation of the Bible started "some time before the middle of the fourth century CE" (Isaac 2013, p. 62). In 330 CE, during the period of Emperor Ezana, Ethiopian Christianity became the official religion of the state and traditional symbols of Axumite coinages started to bear the Cross (Isaac 2013, p. 19).

In Ephraim Issac's detailed and compelling study of Ethiopian Christianity, he quotes the accounts of Abu Salih, a 13th Century Armenian, to show the continuous spiritual genealogy related to the Ark of the Covenant:

The Abyssinians possess also the Ark of the Covenant, in which are the two tablets of stone, inscribed by the finger of God with the commandments which he ordained for the children of Israel. The Ark of the Covenant is placed upon the altar ... and it is overlaid with gold; and upon its upper cover there are crosses of Gold ... The liturgy is celebrated upon the Ark four times in the year ... on the feast of the great Nativity, on the feast of the great Baptism, on the feast of the holy Resurrection, and on the feast of the illuminating Cross. (Abu Salih in Isaac 2013, p. 51)

\section{Western Historiography and Knowledge Grabbing}

Besides creating a spiritual foundation for Ethiopia, the story of the Ark of the Covenant also established the political genealogy of the Ethiopian state from the time of Menelik I in the 10th Century BC to the Last Emperor of the Solomonic Dynasty, Haile Selassie I in 1974. Considered to be the most important text that blends the political and spiritual sensibilities of the nation, Ethiopian kings' legitimacy to the throne depended on their possession of the book. Ephraim Isaac has noted that "each Emperor keeps the manuscript of Kebra Nagast, which tells the story of the founding of the Solomonic Dynasty as a proof of his sacredness" (Isaac 2013, p. 30). 
Western scholars who have studied the history of Ethiopia think of the Kebra Nagast as the earliest source of the concept of nationhood, pre-dating Europe (Levine 2011). The Kebra Nagast was "the foundation of the nation of Ethiopia with particular significance and destiny" and the means of "defending the worth of the national identity" (Levine 1974). Ullendorff has noted that the Kebra Nagast was as important as the Quran for Muslims or the Old Testament for Jews (1965, p. 75): "It is the repository of Ethiopian national and religious feelings, perhaps the truest and most genuine expression of Abyssinian Christianity" (Ullendorff 1965, p. 144). According to Levine, "its appeal transcends the claims of any parochial loyalties in Ethiopia. It glorifies no tribe, no religion, no linguistic group, but the Ethiopian nation under her monarch. It declares this nation superior to all others" (Levine 1974, p. 107).

In 1868, the British army stormed the capital of Emperor Tewodros II at Maqdala. They ransacked the national treasury, looting centuries old manuscripts and other treasures. "Some 200 mules and 15 elephants were needed to carry the loot down to the Dalanta plain" (Pankhurst 1990, p. 224). What they could not take, they burned, leaving no trace of intellectual items behind. At the time, the British Museum had sent Sir Richard Holms to collect items. Holms acquired 350 large manuscripts including two copies of the Kebra Nagast, thirteen replicas of the Ark of the Covenant and other treasures ${ }^{2}$. The loss of the Kebra Nagast was devastating for the successor of Tewodros II, King Emperor Yohannes IV, who immediately wrote to the British Queen saying:

There is a book called 'Kebra Nagast' which contains the law of the whole of Ethiopia and the names of the shums (chiefs), and churches, and provinces are in the book. I pray you find out who has got this book, and send it to me, for in my country people will not obey my orders without it. (Isaac 1971)

The British had taken two copies, so they decided to return one to Ethiopia. Nearly two decades later, Italy was recognised at the Berlin Conference of 1885, where Europeans divided Africa among themselves, as a de jure coloniser of Ethiopia. When Italian forces came to occupy the country, Ethiopians across diverse origins came to defend their Covenant Land. Priests carried the Tabot to the war front. On 1st March 1896, the Italians were defeated at the Battle of Adwa, and Ethiopia remained the only uncolonised land in Africa.

Yet the Western sieges on Ethiopian spiritual and intellectual traditions have continued. I refer to the practice of collecting, holding and utilising Ethiopian intellectual resources as artefacts and properties in Western museums and libraries as knowledge grabbing ${ }^{3}$. Thousands of Ethiopian indigenous manuscripts have been taken by individual travellers, European scholars, soldiers, artefact collectors and their local collaborators. According to official records ${ }^{4}$, the largest Ethiopian manuscripts are currently held in the French National Library, Vatican Library, British Library, Princeton Library and German collections ${ }^{5}$. As a result, local scholars often do not have access to their own textbooks and references. The storing of Tabots in museums is a constant offence against Ethiopian Tewahido faith

2 These treasures are still in the possession of the British. Recently the Victoria \& Albert Museum organised an exhibition titled "Maqdala 1868" to showcase Maqdala treasures. The items displayed represent British imperial legacy rather than Ethiopian heritage (Woldeyes 2018b, 2019).

3 It should be noted that knowledge grabbing can occur through the taking of manuscripts physically or digitally. Digital knowledge grabbing is a form of knowledge grabbing where manuscripts are digitised and held in western digital spaces in the name of 'saving them'. These digital collections are catalogued in western languages and are not accessible to Ethiopian indigenous school students. The EU funded EthioSpare project may be considered as an example of digital knowledge grabbing (Nosnitsin 2010).

4 Recent study by an Ethiopian researcher revealed that there are currently 6928 Ethiopian manuscripts held in western museums and libraries. This figure is based on official records from these institutions and it does not include private and unofficial collections (Tefera 2019). See also, http://www.menestrel.fr/?-Inventaire-des-bibliotheques-et-des-catalogues-desmanuscrits-ethiopiens-\&lang=en.

5 British Library website showcases "Or 719-The Life and Acts of Lālibelā. Ethiopia, c. 1400, a history of King Lālibalā of Lāstā (1162-1221)," as one of its iconic collections. See the British Library Collection Guide of Ethiopian Collections: https://www.bl.uk/collection-guides/ethiopian-collections. 
(Kirby 2004). The looting of sacred texts supported an ethnocentric "thesis that Ethiopians were barbarous" and could not be counted on to write their own histories (Schaefer 2006, p. 350).

Within Western historiography, German orientalist Hiob Ludolf is regarded as the father of modern Ethiopian history. In 1684, he wrote The New History of Ethiopia without setting foot in the country. Ludolf proposed the "hypothesis that the founders of Ethiopian culture were foreign immigrants" (Isaac 2013, p. 1). Since that time, Ethiopian Studies has been established by European scholars with uncontested authority over the interpretation of the country's past and present. The European scholars, and later their Ethiopian followers, advanced the Ludopfian hypothesis that the origin of Ethiopian civilisation was not African. Their view has roots in a:

Hegelian Eurocentric philosophical perspective of history, as it presumes that no Semitic Language is indigenous to Ethiopia...that no indigenous high culture developed in Africa. (Isaac 2013, p. 2)

In 1881, a London publisher reprinted Francisco Alvarez's Narrative of the Portuguese Embassy to Abyssinia during the years 1520-1527, which supported this colonial thesis. The Portuguese Jesuit priest visited Lalibela in 1520, and worried that the world would not believe what he "discovered":

It wearies me to write more of these works, because it seems to me that they will not believe me if I write more, and because as to what I have already written they may accuse me of untruth; therefore I swear by God, in whose power I am, that all that is written is the truth, and there is much more than what I have written and I have left it that they may not tax me with falsehood. (Alvarez 1881, p. 130)

Alvarez further wrote what the locals told him about the construction of the churches: "They told me that the works of these churches were done in twenty-four years, and that this is written, and that they were done by Gibetas, that is, white men" (Alvarez 1881, p. 130). The word "Gibetas" is neither Ge'ez nor Amharic and cannot be translated as "white men". It simply has no meaning in either language, and it is uncertain what language, if any, it originates from.

It is important to note the consequences of Alvares' testimony. Graham Hancock's bestselling book The Sign and the Seal used Alvarez's reference to "white men" to speculate on the involvement of white European Templars in building the churches (Hancock 1992). He related this speculation with the existence of pictures of European angels in the churches ${ }^{6}$. Some have suggested that Lalibela must have had brought Palestinian sculptors when he returned from his pilgrimage to Jerusalem (McGrath 1925). Others suggested Egyptian and Greek workers were employed to build the churches. All of these assumptions do not have tangible evidence, and are based only on the Hegelian paradigm of Africa as a "Dark Continent" without their own systems of learning. Many accounts, in seeking to justify their arguments about foreign influence, degraded the local people as ignorant savages. In 1925, McGrath wrote his travel experience in Lalibela saying:

It seemed that the priests had very little knowledge concerning their churches. Most of them were ignorant men who could not read the splendid old missals which they showed us ... If we asked the chief priest how many churches there were, he had to count them up on his fingers before answering, and he was never able to repeat their names without mistake. (McGrath 1925, p. 517)

What is common in all of these narratives is the consensus that the local history of the churches is false. Local people are therefore not the "owners" of their own history-a narrative that began to separate the people from the churches.

6 It should be noted that there are no European angels carved into the churches. Hancock is referring to European Christian paintings that have been brought in recently. Chojnacki (1964) suggested that western influence on Ethiopian paintings did not appear until the Gondarian era (17-19th Century). 


\section{Translating The Acts of Lalibela: Blessed Bees and Visits to Heaven}

The history of Lalibela ushers in a major shift in power in Ethiopian history. Since the founding of the Axumite dynasty, the centre of political and spiritual life in the country had been Axum, the town in northern Ethiopia where the Ark of the Covenant is placed. In the 900s CE, the centre shifted south to Lasta Roha (Buxton 1970). A small Amharic book published by a Lalibela church scholar, Afe Memihir Alebachew Reta (2009), provides genealogical information that helps us trace the transition. The last Axumite King, Dil Naod, employed a famous general from Lasta Roha named Mera Teklahaimanot, who married his daughter, Mesobe Work. When Dil Naod died without a male successor, Mera Teklahaimanot became king and moved the seat of the empire to Lasta. Here, he founded the Zagwe Dynasty_-11 kings who ruled Ethiopia for 333 years. See Figure 5.

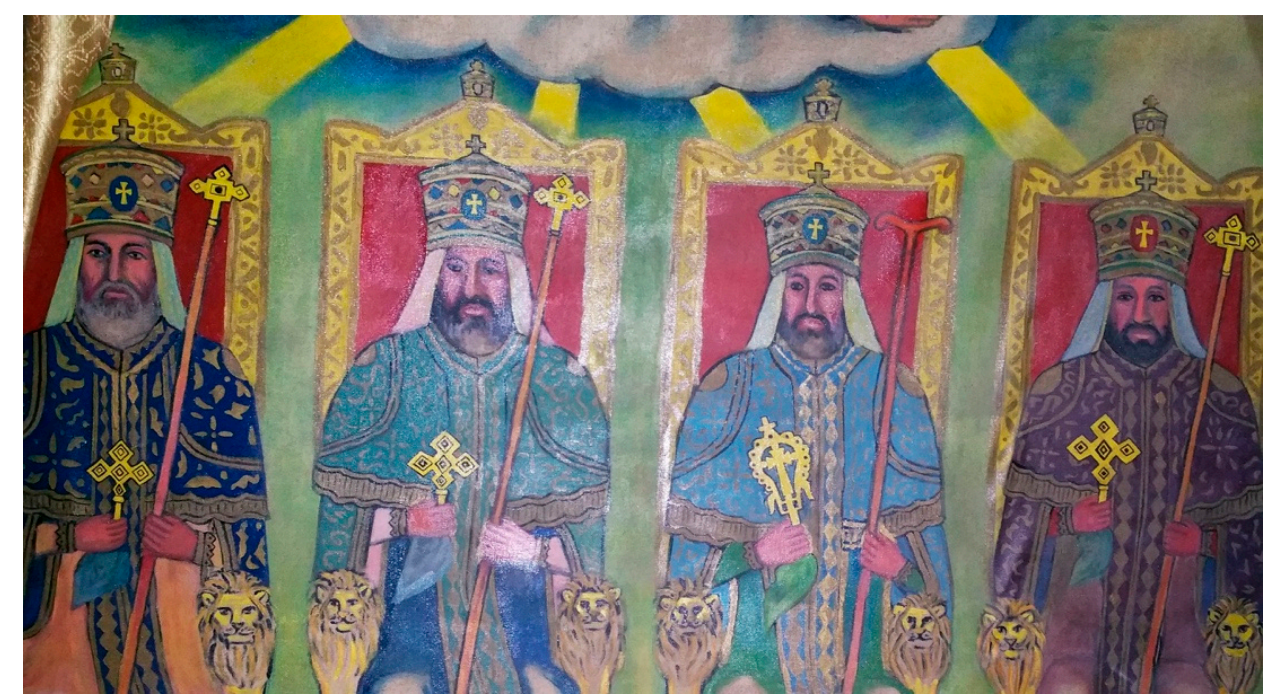

Figure 5. Traditional painting of the four Zagwe Kings: Yimrehane Kirstos, Gebre Mariam, Lalibela and Nea'kuo Leab. (Photograph by Yirga Gelaw Woldeyes 2018).

The story of the rise of the Zagwe dynasty is narrated in the sacred text $7.8 \mathrm{n} n \mathrm{n} \Omega$, The Acts of Lalibela (Gedle Lalibela). Written in Ge'ez on leather papers, the original text is believed to have been written within a hundred years of the building of Lalibela's rock-hewn churches and details the historical, spiritual and philosophical narrative that made Lalibela a spiritual place. Priests read it in Ge'ez for the public, translating and elaborating on it in Amharic, and drawing on principles such as humility as a way of relating with the place. In the past, and even today, passers-by who see

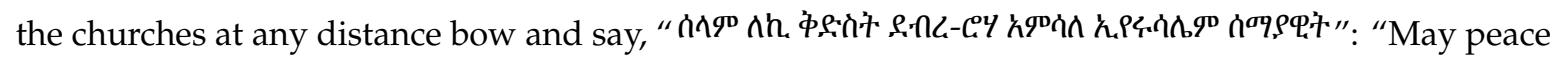
be upon you Holy Place Roha, the likeness of Heavenly Jerusalem". The Acts have recently been translated into Amharic, but no known translations in European languages exist to date. As a native speaker of Amharic with some proficiency in reading Ge'ez, I offer English translations here as a way to make the primary storylines in the text more accessible.

In The Acts of Lalibela, we learn that Mera Teklahaimanot and Mesobe Work had four children-three boys and one girl. One of their sons, Zan Seyoum, married a woman named Etsufit and they had a son, Harboy, and a daughter, Eribqa. Sadly, Etsufit died young, and Zan Seyoum remarried a royal woman named Kereworna. As Zan Seyoum's second wife, Kereworna knew her children would not be first in line to succeed their father, yet she was visited by an angel who told her that she would bear a chosen son. At birth, a large swarm of bees covered the child's body without harming him, which Kereworna saw as sign that he would become a saint and a king. She predicted:

Like bees that are drawn to the nectars of different flowers, this child will be drawn to virtues of diverse colours and smells. He will gather fasting from those who fast, bowing from those who bow, humility form the humble, kindness from the kind, forgiveness from those 
who forgive, charity from the charitable, loving neighbours from those who love, peace from the peaceful. From all good characters that exist, he will not fail to collect a single one. (Acts of Lalibela 2018, pp. 34-35, author's translation)

The Acts states that the life of Lalibela resembled the life of Jesus Christ (2018 [2010 Eth.C], p. 48). Like Jesus, Lalibela was born on 7th January (Jvin Jesus's birth was accompanied with the appearance of an angel as a star; Lalibela's birth with angels who appeared as bees. At the age of six, Lalibela started to study scripture under Memmhir Daniel. When he was a teenager, both of his parents died and his half-brother Harboy was throned as Gebra Mariam (Servant of Mary). After grieving for his parents, Lalibela travelled to study with the renowned scholar Memhir Kefa in Gojam.

Although he did not have political aspirations, the story of the bees and the prophesy that Lalibela would become king created anxiety in the palace. One day, while in the house of the king, Lalibela was offered a drink, apparently by a servant of Eribqa, his half-sister. The servant did not know that it was poisoned with hemlock. As was customary to do, he tasted it, vomited, and died immediately. A dog ran in and tasted the vomit and also died. According to The Acts, Lalibela (See Figure 6) became so remorseful for these two innocent victims that he drank the rest of the poison, and collapsed. People surrounded him, and found that his body was warm but his soul had gone. As it is not proper to bury a body while warm, they waited for three days and three nights.

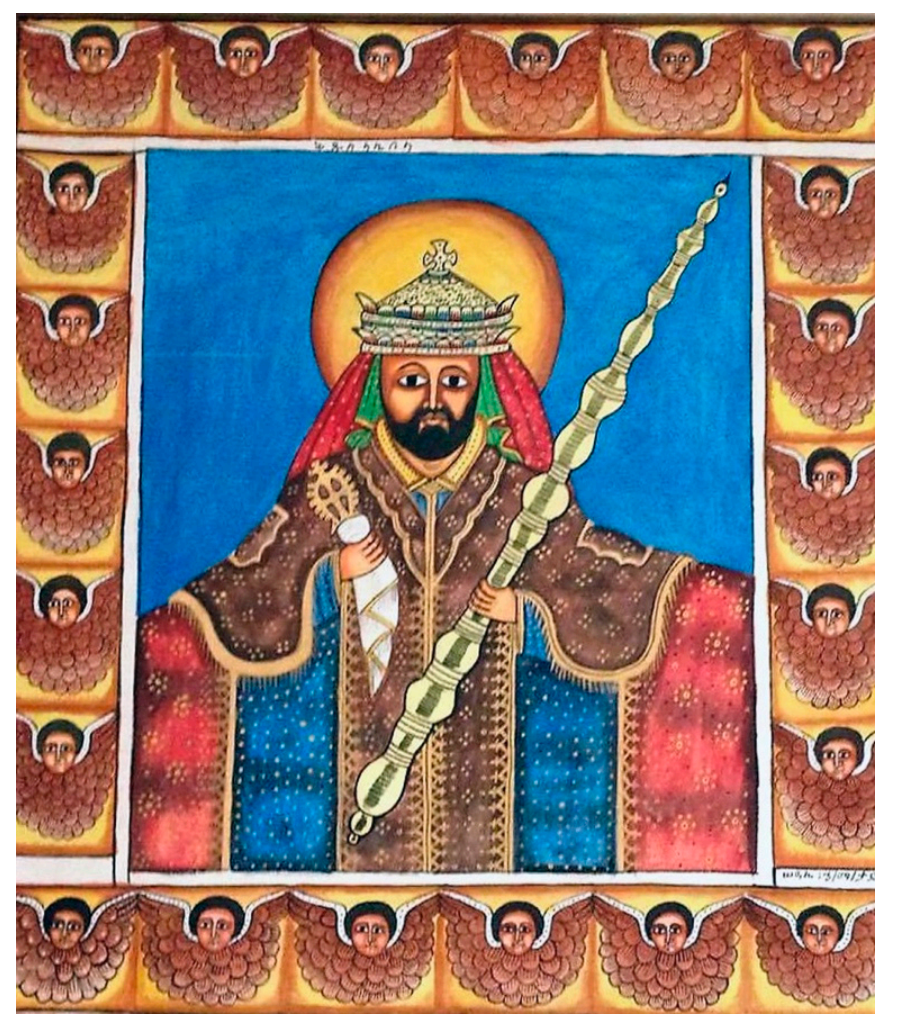

Figure 6. A traditional painting of Lalibela, surrounded by angels, by local artist Haile Mariam Tadesse. Lalibela as a priest king holds his unique cross "Afro Ayigeba" showing his priesthood and a staff that shows his authority as king. The representation of Lalibela richly adorned in lavish robes and a crown is meant to represent Lalibela's holiness. (Image from Yirga Gelaw Woldeyes' private collection, 2018).

The Acts narrates the ascension of the soul of Lalibela to the Seven Heavens where angels and saints greeted him with reverence and joy. At the seventh heaven, Egziabher appeared before Lalibela and told him that he was destined to reveal a heavenly place on earth. Then, in a vision, he showed him the rock buildings and the "metallic instruments" Lalibela would use to reveal them (2019 [2010 
Eth.C]). After the detailed promises, Egziabher anointed Lalibela and told him that only for the sake of revealing/building the churches, Lalibela shall become King of Ethiopia. Then, Egziabher places his right hand on Lalibela's head to make him strong "like a rock" and says, "in all of your efforts the angels will be there to help you" (2018 [2010 Eth. C], p. 104).

After three days, Lalibela's soul returned to his body and he woke up. He decided to live as a hermit in a forest until an angel advised him to go to town, get married, and fulfil the plan Egziabher gave him. He married Meskel Kebra, travelled to Jerusalem, and upon his return, his brother wilfully handed the throne to Lalibela and crowned him with the name Gebre Meskel. As soon as he became king, Lalibela started preparation for the holy task of carving the churches.

\section{Wisdom through Humility: Carving the New Jerusalem}

The rock-hewn churches of Lalibela are frequently the subject of speculation, with many wondering how they were carved with such precision in the 12th century. The architectural work inside and outside the churches, including the underground and surrounding tunnels, has a strong connection in style and purpose with Axumite steles and other monuments in Ethiopia. David Buxton shows the millennial connections of architectural style between Lalibela, Axum and other places (1970). Several other churches chiselled from rocks such as Bilbala Kirkos, Bilbala Giorgis and Arbaety Ensisa are found scattered in Lasta, Tigray, Gondar, Showa and other areas, showing the tradition is deeply imbedded in the spiritual genealogy and identity of Ethiopia.

Modern scholars often look for detailed physical evidence to be able to explain the process. According to the local spiritual belief in Lalibela, questions around how the churches were physically built are irrelevant because it is believed that the maker of the churches is Egziabher, who created them when He created the world, and hid them "in the heart of the earth" until the time came to reveal them to the world through His humble servant (Acts of Lalibela 2018, p. 102). Egziabher spoke to Lalibela

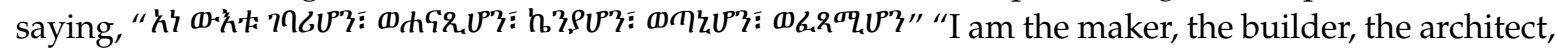
the designer, and the accomplisher" (2018 [2010 Eth.C], p. 102). The Acts further notes that the Lalibela churches will exist till the coming of the Heavenly Jerusalem at the end of the world (2018 [2010 Eth.C], p. 214).

In describing the churches, The Acts takes a place-based perspective that gives agency and power to the rock churches as living entities endowed with the power to heal, teach, and bless the people. "Whosoever walks to (pray in) Lalibela's churches would walk in the Heavenly Jerusalem in the afterlife" (2018 [2010 Eth.C], p. 110). It repeatedly emphasises that these churches are not like any other church on Earth (See Figure 7). They are more significant than the Tent of Moses, the Temple of Solomon or any other place of worship (2018 [2010 Eth.C], p. 214).

The Acts and other spiritual texts ask not how Lalibela and his workers carved the churches, but how did Lalibela became worthy enough for Egziabher to reveal them to him. In other words, how could someone gain wisdom, the power to see what is hidden to others? According to Ethiopian philosophy by Skendes the Wise, "Wisdom is ... the eye of the soul; it sees all that is concealed and secret. It calls knowledge conscience. It inquiries into the wonders of the High God light that fills the soul" (Sumner 1981, p. 54). The Kebra Nagast further interprets wisdom as compassion or humility and the fear of Egziabher (1932, p. 24-27). In Ethiopian traditional belief, wisdom is only ever possible through humility ( power are incapable of revealing valuable things. One can only express the work of Egziabher by renouncing his/her power through $\lambda^{\prime} n_{b} o_{b}$ (ongoing fasting and prayer). Humility suggests a wilful movement to the bottom, a permanent journey to the holy place of Egziabher. The human is not the master, the builder, nor the author of events that occur in place.

This path to wisdom was practiced by Lalibela himself when he assumed the throne. "[H]e submitted himself to a fast more severe than that of monks, because to him the kingship appeared as the monastic life" (Perruchon quoted in Kaplan 1984, p. 12). Human beings were only permitted to see, and then take part in revealing, the pre-existing churches through this epistemology. Consequently, 
the scriptures follow spiritual themes with less technical details, although they do emphasise that the churches became visible to humans through the torturous pain and labouring effort of Lalibela and his workers.

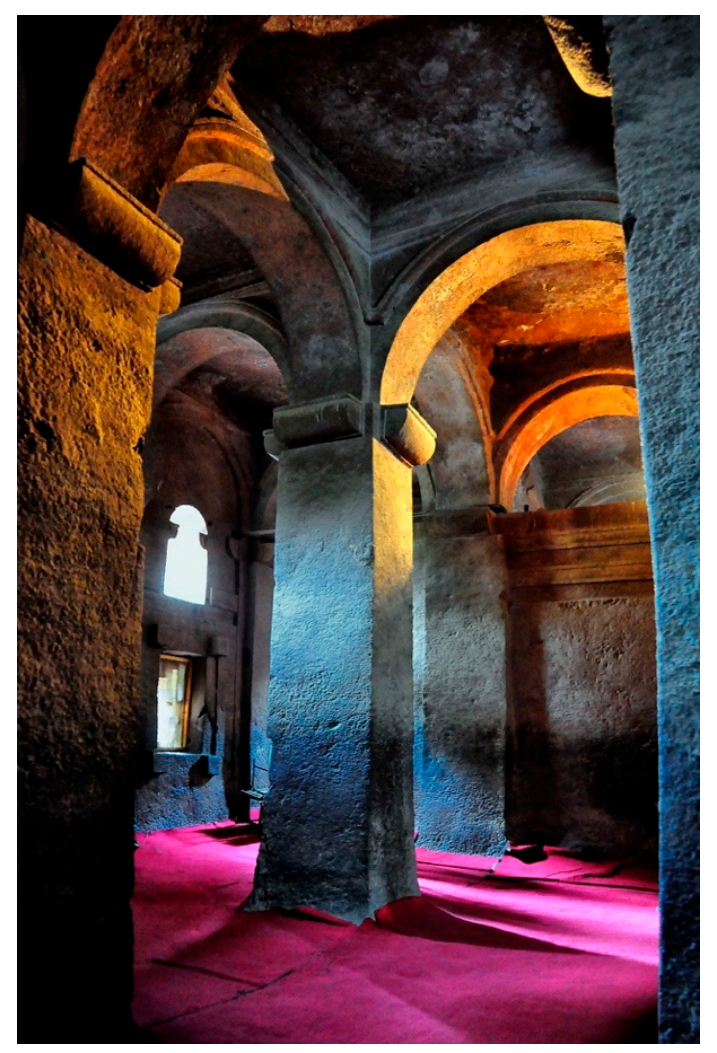

Figure 7. Inside Bete Medhanialem, which was hallowed out of rock in Lalibela, and said to be the largest rock-hewn church in the world. (Photograph by Rod Waddington, courtesy of Creative Commons Share-Alike).

Other sources point to more physical details of construction. Afe Memihir Alebachew Reta shows that there was a detailed local history on how the churches were made (Reta 2009, pp. 42-43). First, there was a phase of preparation that included a careful study of the location and a generous payment of compensation for Lady Keyit, a woman who owned the Roha area at that time. Then, Lalibela appointed Sedi Meskel from Bugna to recruit the best workers and supervise the production of tools. The Bugna area was famous for carving out rock hewn churches since the Axumite era ${ }^{7}$. The preparation took nine years. Before the work commenced, Lalibela undertook int $i \cdot \eta_{b}$ : three rounds of seven days prayer and fasting, with complete isolation from the world. After Egziabher revealed himself to Lalibela, angels and humans started to build the Second Jerusalem together. The Acts explains that the angels were visible only to Lalibela, not to the workers. The angels provided the measurements and at night, when the workers slept, continued the work of carving the churches. All of them were carving a place that had already been made at the beginning of the world.

Throughout his reign, Lalibela refused to benefit from the proceeds of his rule as king. Instead, all of his income came from his own labour and he ate only three gurshas (bites) per day. All of his belongings and incomes were regularly distributed to the poor. He did not build a palace for himself or wear gold and silver like kings; he did not apply the rule of servitude over his subjects. He treated

7 Examples of pre-Lalibela rock hewn churches that were carved during Emperor Caleb in the 6th Century in the Bugna area include Bilbala Kirkos, Bilbala Giyorgis, Arbaetu Ensisa, Wukro and others. See also (Mengistu 2018). 
his servants as his own children. He had no enemies to fight and his empire was peaceful. He died at the age of 97 and was buried in the House of Golegota-Selassie, one of the churches he built (Reta 2009, p. 37). Finally, The Acts casts the life of Lalibela as an example for people who may wish to come to

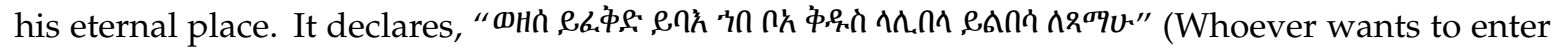

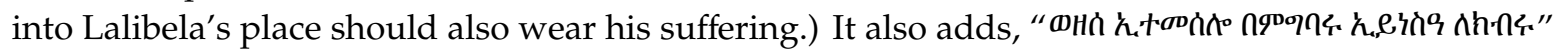
(Those who do not follow his deeds shall not inherit his glory) (Acts of Lalibela 2018, p. 256).

The historian Tekeste Negash has shown how the history of the Zagwe period, including that of Lalibela, has been dismissed by two waves of Eurocentric publications (Negash 2003). Firstly, Western scholars such as Conti Rossini advanced the thesis that Ethiopian civilisation, including the achievements in Axum and Lalibela, were not of indigenous origin. Secondly, Ethiopian scholars began to take the history of Europe as a template to write Ethiopia's history (Kebede 2003). Both groups referred to the period of Zagwe as "The Dark Age". Negash argues that despite its unsurpassed political and social stability, scholars did not study the Zagwe period based on its own hagiographical sources. They preferred historical sources from Royal Chronicles that emphasise narratives of violent political events, as opposed to hagiographical sources that emphasise spiritual subjects. Therefore, the reference to the Dark Age, due to lack of evidence regarding war, is ideological. Negash's argument is corroborated by The Acts of Lalibela, which explains that there was no war or cruelty during the reign of Lalibela.

\section{Legacy of The Acts: Cultural Life of the Churches}

With the fall of the Zagwe dynasty, Lalibela's purpose as a political capital declined but it remained as an important centre of spiritual life. By the 20th century, three important groups of people lived very closely with the churches. Within the churches themselves, hermits lived in grave-like caves that were originally built with the churches. They spent day and night in prayer, and rarely left their place or made any contact with people. Occasionally, they went out to warn people to behave in accordance with the sanctity of the place or pass important messages that they claimed were from Egziabher. Inspired by the life of Lalibela as written in The Acts, they kept no belongings except their prayer book, prayer beads, and an iron prayer staff with a cross on the top.

Behind the House of Amanuel, monks and nuns created a monastic community. Members brought their property to the community and lived together as a family. Some gave spiritual guidance and support to distressed or vulnerable individuals. Nuns supported church services by preparing the special wheat that would be used in Holy Communion. They also collected flour from residents of the

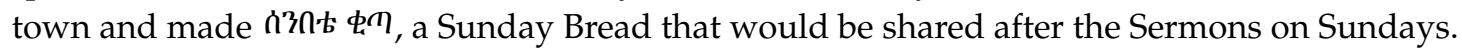

Outside the church compound, a neighbouring community composed of priests (See Figure 8), mergetas (highly educated religious scholars) and their disciples, artisans, and lay community members lived surrounding the churches. Their lives were based on traditional customs and institutions such as Edir (burial associations) and Mahiber (sharing food and drink in commemoration of a saint or an angel). The poor, the disabled, the stranger and the elderly often lived near or within these communities, benefiting from the support of spiritual feasts and from the charitable acts of the town's residents or visitors. They also received spiritual support and guidance from the clergy. Under the trees near the churches, elders and priests held meetings mediating conflicts. 


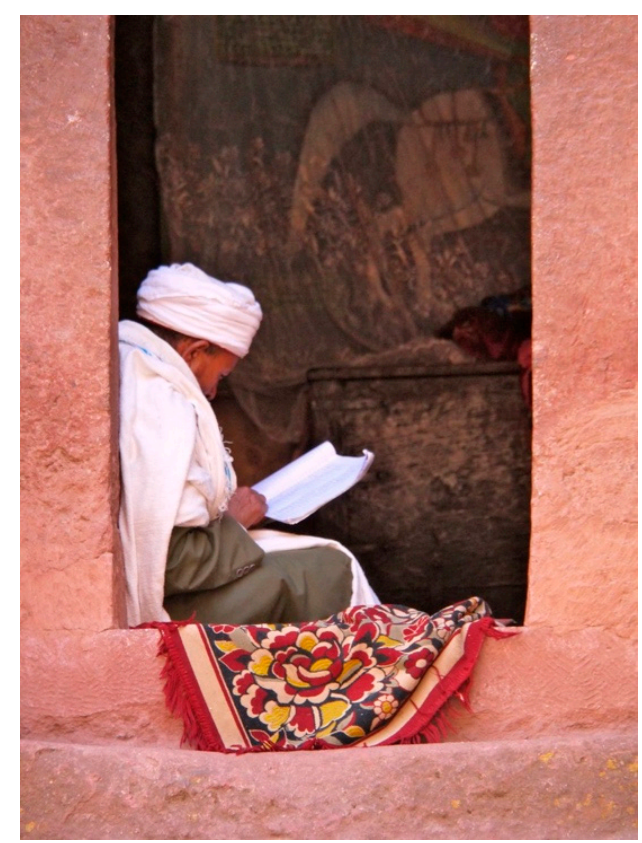

Figure 8. A priest reading by an entrance to Bete Ghiorghis (House of St. George). (Photograph by Martijn Munneke, courtesy of Creative Commons Attribution).

Relatives and neighbours gathered near the church to mourn for the dead. For the residents of the church area, accepting pilgrims and showing them the churches was an important aspect of fulfilling their spiritual duty as inheritors of the glory of Lalibela, as indicated in The Acts. Many of these people had two-story round tukul homes that were made from the red stone of the area. People lived in the upper floor and used the lower floor as a kitchen and store. The staircase that would lead to the upper floor was constructed from the outside. These homes were recognised by UNESCO as part of the cultural tradition and living civilisation of the area:

The whole of Lalibela offers an exceptional testimony to the medieval and post-medieval civilization of Ethiopia, including, next to the eleven churches, the extensive remains of traditional, two storey circular village houses with interior ${ }^{8}$ staircases and thatched roofs. (UNESCO Website 1978)

Traditional schools (See Figure 9) were in existence around the church neighbourhood for centuries. Scholars of the traditional school system, who graduated from the country's centres of excellence in Gojam, Gondar, Wollo and Showa " "33C a start teaching a special discipline in the traditional education system, often by sitting at the centre of a large number of students who surrounded the teacher. Lessons were delivered at night and during holydays. Senior students taught juniors and the head master taught the seniors. The students gathered food from the neighbours and ate together. As most students came from faraway places, the teachers allowed them to make temporary tukuls in their own backyard. Since knowledge was regarded as the gift of God, tuition fees were unknown and students were not expected to pay rent for their accommodation. The disciplines included, but were not limited to, the proper reading and singing of sacred manuscripts, composing poems with diverse meanings, the art of proper standing and moving the staff during singing, the interpretation of canonical texts, mathematical computation of time, preparation of leather manuscripts, sacred painting, traditional medicine and others (Kalewolde 1965).

8 The staircases are constructed from the outside. There are no interior staircases as stipulated in the UNESCO's OUV document. This is an error. See also Aauland's note (1985, p. 51). 


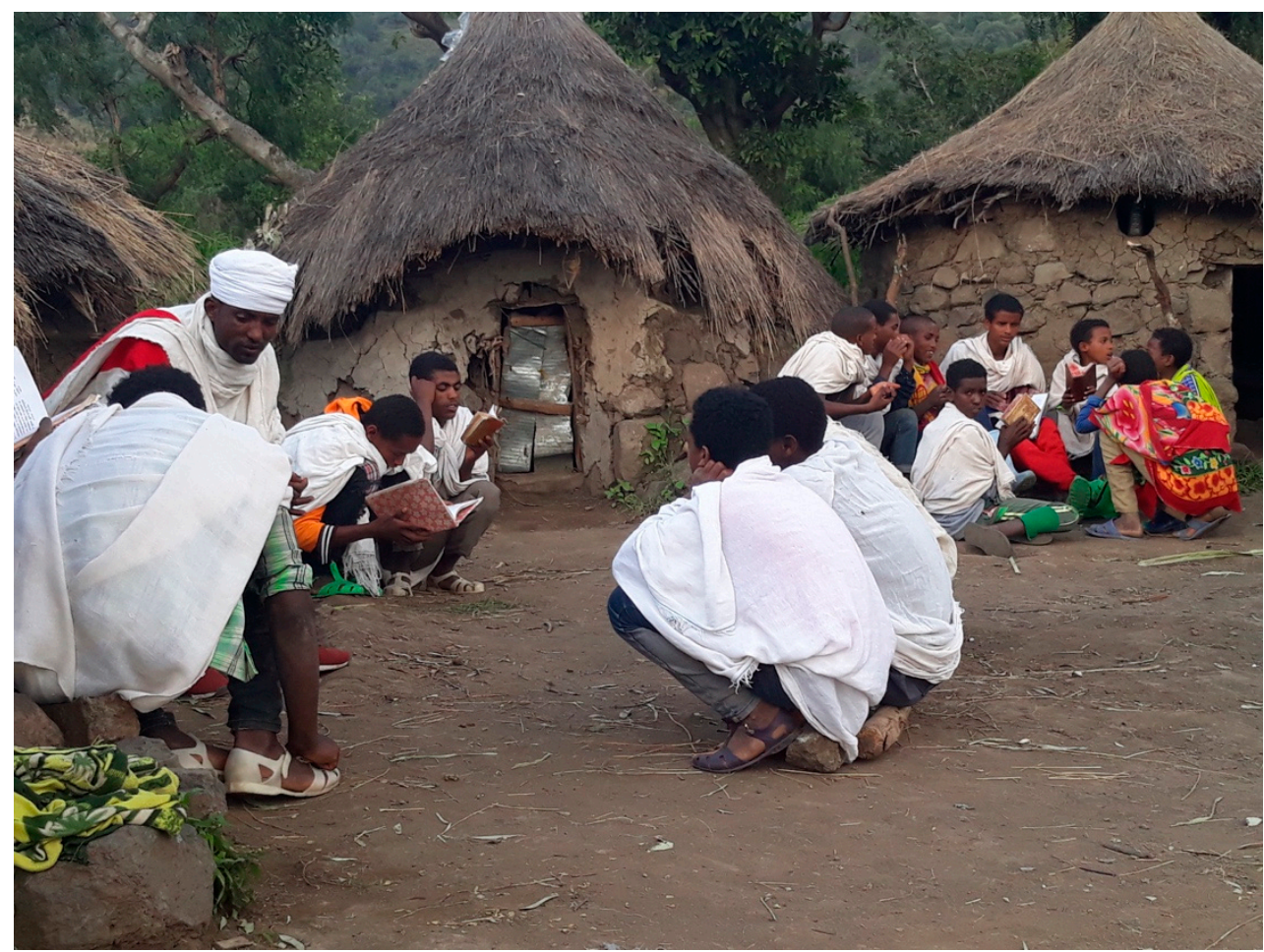

Figure 9. Traditional schools of learning in Neakuto Leab, near Lalibela in 2019. (Photograph by Yirga Gelaw Woldeyes 2019).

The names of these scholars are not known in Western scholarship, but they raised generations of Ethiopians with the help of The Acts and other indigenous sources (See Figures 10 and 11). Mergeta Wube had a famous school dedicated to the written music of the church at his home near Bete Amanuel. Mergeta Afework painted the history of Lalibela based on The Acts. Others, like Mergeta Semawu, wrote leather manuscripts using traditionally prepared ink and animal skin. Afememhir Alebachew copied The Acts of Lalibela from a Ge'ez original, translating it into Amharic at the same time. Kies Kassie taught the public tirelessly, standing from the rock cliff facing the church of Mariyam. Riese Debir (head of the place) Gebra Meskel Amagnu's singing of the sacred words was said to parallel only with angels. Although their number declined in time, sculptors, book binders, cross makers, weavers, and traditional restaurant owners existed side by side for centuries.

Local craftsmen and artisans conducted small conservation work on the churches when it was needed. They repaired damaged walkways and plastered small cracks by mixing the red soil with water and hay. They applied herbs and animal urine to kill the roots of small plants that grew on the churches. The nuns and hermits cleaned the churches and watered the nearby plants regularly (Ayalew 2016).

Lalibela attracts a large crowd of pilgrims especially on Ethiopian Christmas day. The pilgrims

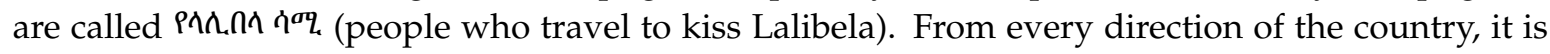
customary to find a caravan of people walking towards Lalibela on foot. As provided in The Acts, every footstep towards Lalibela has spiritual reward. People who meet the pilgrims along their way took them in to their homes "for the sake of Saint Lalibela". It is believed that the hosts would share from the blessings of the pilgrims by helping them. The songs of the pilgrims embody the uniqueness and holiness of the body of the churches, the rock, the soil, the plants and the air as the following common song suggests: 


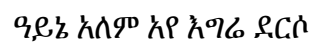

My feet arrived and my eyes saw happiness

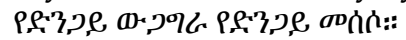

A stone wall and a stone mortar

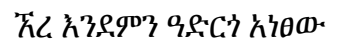

How did he built it

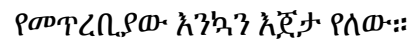

When the axe did not have a handle?

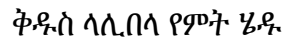

Those who travel to Lalibela

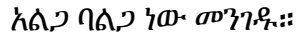

The road is meshed with bed and comfort.

When they return, pilgrims take soil from Lalibela's grave. Honey still has a special place in the whole region. Bee hives that naturally occur in rock hewn churches in the Lasta area are carefully harvested so that the holy honey can be given as blessings. The bees in the rock-hewn church of Bilbala Giorgis, some $30 \mathrm{~km}$ from Lalibela, still provides honey as spiritual medicine, like the soil of Lalibela.

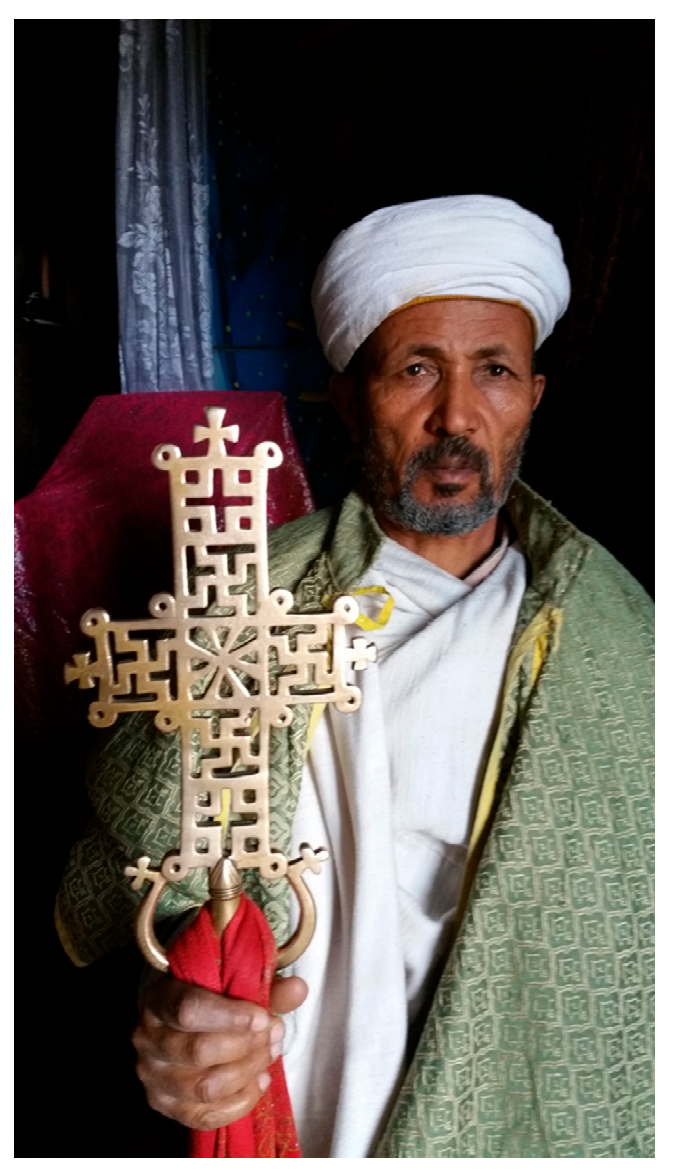

Figure 10. A priest holds one of the ancient crosses at Bete Maskel. The signs on the cross are also carved into the windows of some of the churches. (Photograph by Yirga Gelaw Woldeyes 2019). 


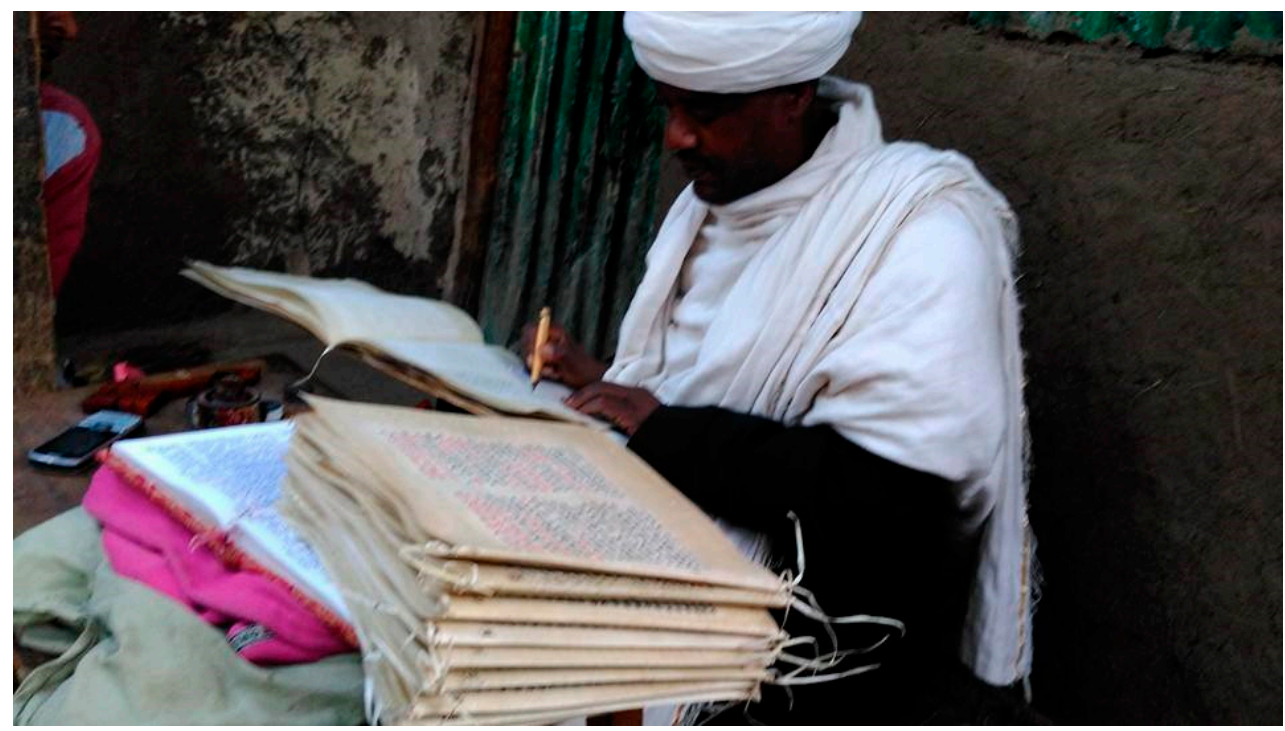

Figure 11. Mergeta Semawu reinscribing a Ge'ez manuscript at his home. (Photograph by Yirga Gelaw Woldeyes 2018).

\section{Native Colonialism: The Impact of Conservation and Tourism}

In the last two decades, the state has adopted the Growth and Transformation Plan (GTP) to achieve the status of a middle-income economy as determined by the World Bank (MoFED 2010). This plan has enormous impact on facilitating the conversion of cultural, natural and other resources into foreign currency. For instance, The GTP advances the conversion of rural land to cash by leasing large farms to investors in a campaign many regard as "land grabbing" or "land to investors" (Rahmato 2014, 2011; Human Rights Watch 2012). Recent practices of "taking to preserve" Ethiopian manuscripts, physically or digitally, may also be considered within the paradigms of land and knowledge grabbing. In 2010, the government adopted the Ethiopian Tourism Development Program with the aim of making tourism a “No.1 export earner" (World Bank 2008, 2009).

Lalibela has become an important site for tourism in Ethiopia, causing significant disruptions to how the local people view and relate to the churches. However, interventions that challenge the sanctity of the place started long before the GTP. Since the 1920s, Lalibela become an important means of strengthening diplomatic ties between Ethiopia and western countries. Foreign governments offered "scientific" methods of conserving the churches. The narrative of science excluded traditional conservation methods as backward. The churches were no longer considered "alive". They are now regarded as "sick", endangered, and in need of saving. Conservation work in Lalibela follows a material-based approach (Negussie 2010). This approach means that "exclusive responsibility over the definition and conservation of heritage is in the hands of heritage authorities (mostly state appointed), manned by political officials and especially conservation professionals. Community is not taken into account" (Poulios 2014, p. 19).

The modern conservation movement began in 1954 when an Italian consultant firm called Bastiano, Rosetta and Cambusi (elders call him Camboos) coated the Houses of Medhanialem and Amanuel with bituminous fluid and drove nails into the rock to support the bituminous layer. They then painted it with red ink. The roof of Bete Medhanialem was completely sealed with cement and iron sheets. New stairways and partition walls were made "with little grace but too much cement" (Aalund 1985, p. 52). The interventions caused significant, irreversible damage to the churches that would require further conservation work. Indeed, in 1966, a restoration campaign led by Sandro Angeleni commenced under International Fund for Monuments (IMF 1967). They pulled out the nails; scrubbed the red paint, cement and bituminous fluid, and left the churches severely pockmarked, 
which are visible reminders of the trauma in the faces of the churches. Prayers were often held to Egziabher to avoid further "menace" from happening again.

In 1978, the inscription of Lalibela as a UNESCO World Heritage site began a complicated dynamic with the political regimes in Ethiopia and the local people. Although the Marxist-Leninist regime was militant against indigenous knowledge and spirituality, inscription afforded the state antiquity, legitimacy, and the power to intervene in the management of the churches. It afforded legitimacy to new secular actors to speak about the church without using the language of the priests, and to perform activities without the full consent of the clergy or the local people. It provided new concepts such as "heritage", "property", "conservation" and "authenticity" that do not incorporate the meanings and experiences local people have had with the churches in the region. The World Heritage Committee insisted on the creation of boundaries, buffer zones, and conservation zones around "the property".

Traditionally, there was no border between the people and the Lalibela churches. However, in 1984, an attempt was made to build a wall by incorporating 25 hectares of land, $40 \%$ of which was occupied by 258 households (ESTDP 2009, p. 14). The wall remained unfinished. In 1999, the Master Plan of the town of Lalibela passed a moratorium that people living in the church area were not to erect additional buildings or repair their homes. They were denied municipality services and were left to suffer unbearable consequences that would eventually justify their removal from their homes in 2009.

Just before the relocation of residents, in 2008, another conservation project was funded by the European Union with 7.4 million Euro being allocated for the construction of heavy metal shelters over five churches (see Figure 12). The purpose of the shelters was to "protect the churches from sun and rain and permit restoration that could absolutely not be postponed" (Teprin Associati 2010, p. 5). The same year, the local church administration decided to expel the hermits from their grave-like caves inside the compound. The second victims were the beggars who would sit at the entrances of the churches to receive alms from tourists and other visitors. Local authorities created a shelter where they would be provided with some food while staying away from the church area. These developments that see the churches as a physical "property" that generates tourist dollars is a result of epistemic violence, the privileging of foreign knowledge and values over local ones such as The Acts of Lalibela.

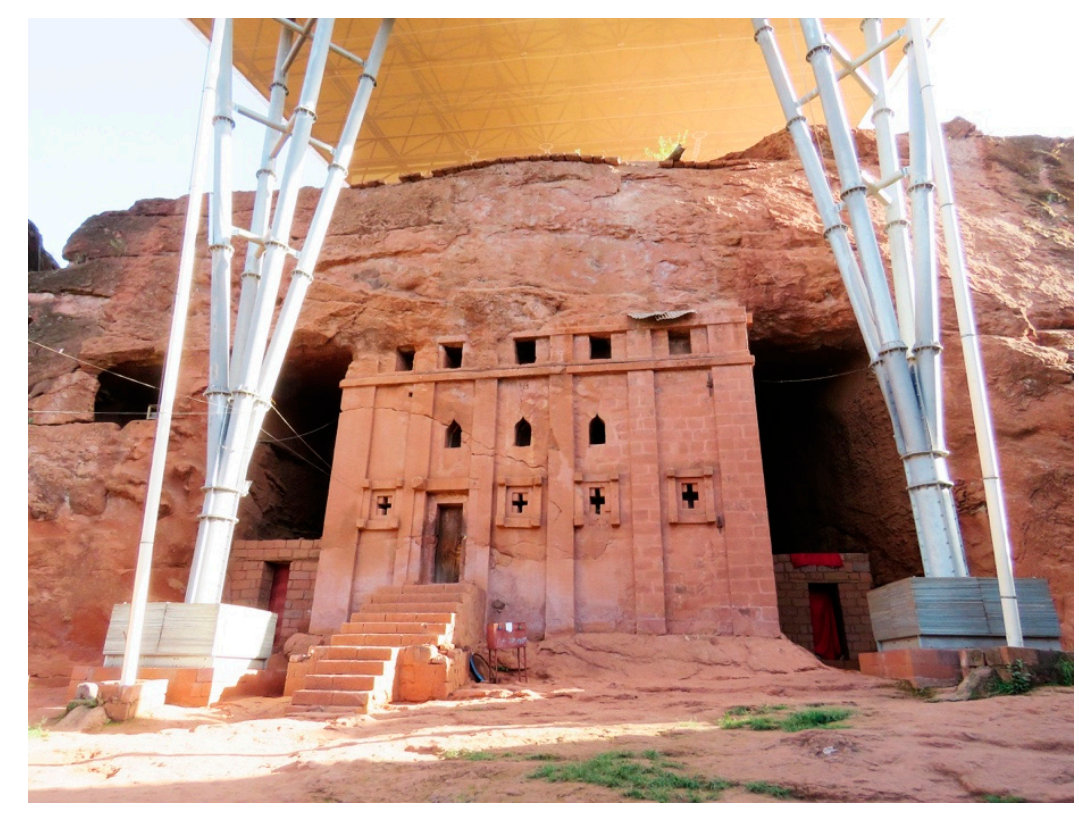

Figure 12. Bete Abba Libanos under the EU funded shelters. According to UNESCO, "shelter constructed over Biete Abba Libanos was erected against the advice of earlier missions and the Advisory Bodies" (UNESCO 2018, p. 12). (Photograph from 2012 by Chuck Moravec, courtesy of Creative Commons Attribution.). 
A year later after the shelters were funded, in 2009, the Ethiopian Sustainable Tourism Development Program (ESTDP), backed by a $\$ 35$ million loan from the World Bank, introduced a series of measures that negated the spiritual purpose of Lalibela (2009). The objective of ESTDP is making tourism "the No.1 export earner in the Ethiopian economy through investing in improved product and market development that encourages more tourists to spend more and stay longer" (World Bank 2008). The World Bank provided the strategy to achieve "the objective that the historic and cultural sites need to become productive sources of jobs, incomes and economic growth for Ethiopians" (2008). The Bank compared the number of tourists who visited Lalibela $(18,000)$ to other places such as Angkor Wat in Cambodia $(320,000)$ in 2004. It argued that Lalibela had low quality infrastructure but expensive services, making it less attractive for tourists to stay longer. The Bank suggested a neoliberal model for tourism in Ethiopia that had developed around Angkor Wat:

Cambodia has outsourced virtually the entire tourist industry to the private sector. A tourist arriving will likely fly on a privately-owned plane (Bangkok Airways), land at a privately managed airport (Siem Reap International), be handled by a private firm at the airport (CAMS), take a private car to a privately-owned hotel (over forty new hotels built over the past five years), be handled by a private tour operator (foreign or domestic) and visit Angkor Wat temple, the maintenance of which is outsourced to a private firm. This has allowed the sector phenomenal growth without demanding massive public-sector investments or new civil servants. (World Bank 2006, p. 19)

In its report, the World Bank does not refer to the history of Angkor Wat's original inhabitants: monks, local people, and artisans who were dispossessed of their holy temples in the name of heritage protection since the French colonial period (Miura 2013). The comparison between Lalibela and Angkor Wat suggests the intent to bring the sacred place to the market by disrupting, freezing, or eradicating non-commercial realities that exist at the site and making Lalibela available exclusively for tourists. The World Bank's suggestion to repeat the same displacement as Angkor Wat condones native colonialism and dispossession in the name of economic benefits for the private sector.

Dispossession was a direct consequence of this. In 2009, the implementation of ESTD involved the removal of people in church area. The households within the "church compound" were divided as follows:

(1) those who own the house they live in (196),

(2) tenants in kebele houses (62),

(3) others who live in church-built shelters without rent, and

(4) 32 Nuns and monks who live in the monastery belonging to the church.

(5) Households who use their residence as income generating space (15) (ESTDP 2009, p. 20)

To pressure people to leave, anyone living in the demarcated church area was denied municipal services based on the Master Plan of 1999. The ESTDP's Resettlement Policy Framework considered the removal of the people in the church area as the "cleaning" of the site:

Residents use on-site sanitation; most of it is even open sanitation system. This has made the church compound unclean. The occupation of lands higher than the historic and cultural sites funnels run-off water to the church compound. (ESTDP 2009, p. 17)

Rather than helping with better sanitation, the program only encouraged resettlement. The plan identified a location in the outskirts of the town, three $\mathrm{km}$ away from the churches, by displacing small holder farmers from their farmland at cheap prices. Residents were not allowed to rebuild the tukul style homes because they did not meet the new master plan's standards of a minimum of $5 \times 7$ corrugated roofing. Residents still complain that post-resettlement development plans have not been realised and the displaced live without electricity, water and sewerage services. To date, the displaced have no voice. They have lost their homes and their relationship with the living churches of Lalibela. 
Some of the displaced elders now gather on Sunday mornings under a big tree some 3 kms away from the churches. They cannot walk to the churches, nor can they afford transport. A recent UNESCO Mission Report recognised the impact of the displacement:

As a result of these activities, the immediate vicinity of the churches is now devoid of local people. There exists only some few traditional "tukuls", most of them in a very delicate state of conservation since many collapsed during the demolition works at the site. The mission visited some hidden private places within the properties, inhabited by a small pious community of women monks, and it is reported that there are still some parts of the historic settlement in place. But the most substantial part of the traditional village within the limits of the World Heritage property-mentioned in the ICOMOS evaluation of 1978 to be the holder of the medieval traditions of the site-no longer exists. (UNESCO 2018, p. 27)

In addition to the pain of displacement, the local people live in fear of what may happen to their churches if the shelters remain. More than a decade since the construction of the EU funded metal structures, not a single restoration work has taken place in the sheltered churches. The UNESCO Mission Report discovered that the shelters have allowed the clay rock to dry out: "as a result of the microclimate that has existed under the shelter; the completely dry environment has led to significant crumbling of the rock" (UNESCO 2018, p. 4). Moreover, "the mission has observed at several locations a widening of the joints between the flanges of the columns" (UNESCO 2018, p. 33). Mamite Gelaw, a 56 years old resident of the nearby church area, explained the impact:

We live with the fear. For real, we don't sleep. It is a nightmare for us. When the heavy wind blows and when it rains, we have to pray the Almighty to bring us a better solution and to remove the giant shelters from our holy churches. They told me that UNESCO made these structures but why did they put us in this terrible situation? Anyways, the solution should come from the sky, not from the humans. (quoted in Ayalew 2016, p. 62)

The construction plans were not translated into the local language. Some of the project documents given to local committees were written in English with highly technical terms. Ayalew (2016) noted that when the priests tried to stop conservation workers from chiselling the rock, they were warned that they would be forced to pay the wages of the workers that became idle as a result of their protest. Locals believe that the churches are tortured like Christ on the cross. Reports of damage during construction have not been investigated. On 7 October 2018, thousands of people protested, condemning the reluctance of the ARCCH and UNESCO to address the threat posed by the EU funded shelters (Flanagan 2018). Further damage caused to the churches permit an even more vigorous intervention by experts, appeal for more funding by the heritage authority, and an increasingly diminished role to the local people and their relationship with the churches (Woldeyes 2018a).

In the same year as the protests, UNESCO's Mission Report warned that there is "a tendency on the regional and local level to 'commodify Lalibela', which, if continued without reflection, might pose threats to the values of the property in the future" (2018, p. 39). Plans to address the image problems in tourism development in Lalibela include building a comfortable hotel with distant views of the churches, tourist guides, well cooked food and clean water, a working camera, traditional entertainment, and currency exchange. In recent years, the hilltops and plains of the town have been put on lease, and locations have taken new value depending on the views they provide to the sight of the tourist. With the increasing marginalisation of indigenous life, the tourist gaze becomes the norm-setter of local life. It monitors and evaluates local people's behaviour in relation to its own expectations.

\section{Conclusions: Resilience of Spiritual Genealogy and Ongoing Challenges}

There are many factors that challenge the continuity of the spiritual genealogy of Lalibela. Since my childhood, I have witnessed changes, challenges and fears that affect this tradition. Yet it is 
important to emphasise that Lalibela is still regarded by many as a living place. Monks, priests and local residents bow, communicate, and sing to it every day. People eat yelalibela afer (the soil of Lalibela) for medicinal purposes. Afro-Ayigeba, which translates as "it won't enter in shame", is the name of the famous cross that was used by Lalibela to bless his people. It was stolen, sold to a Belgian collector for 25,000 USD, but later returned to the people. Today, as in the past, this cross in Bete Medhanialem is used to heal the infirmities of the soul and the body. The biblical names of the surrounding rivers, mountains, caves, passages and the arrangement of the churches are all used to narrate spiritual mysteries, especially the mystery of Heaven (mistre semayat).

Classes still take place in the backyard of a scholar's own home (See Figure 13). Students come from far and near and make small round huts. They have to survive by begging or working manual labour during the day. At night, they gather around the teacher and study the scripture and the Ge'ez language by heart. The manual production of numerous manuscripts, including the Acts, still continue through the efforts of committed individuals. As previously mentioned, Afe Memhir Alebachew Reta made a richly calligraphic version of The Acts and more, while translating the Ge'ez text into Amharic. Mergeta Semawu copies ancient manuscripts with musical notations known as Degwa. Hailemariam Tadesse paints angels and saints following the indigenous style. These and other scholars and artists have acquired the ancient skills of preparing strong ink, hide, and calligraphy bamboo pens. None of their efforts are remunerated or regarded as parts of knowledge by the Ethiopian government. Yet, as these practices are deeply rooted in the spiritual genealogy of their lives, in their very identity as faithful scholars, they view their wisdom and skills as a gift that originated from Egziabher and pass them on across generations without charge. Whoever gains the chance to learn these skills also receives the responsibility to pass it on to others for free.

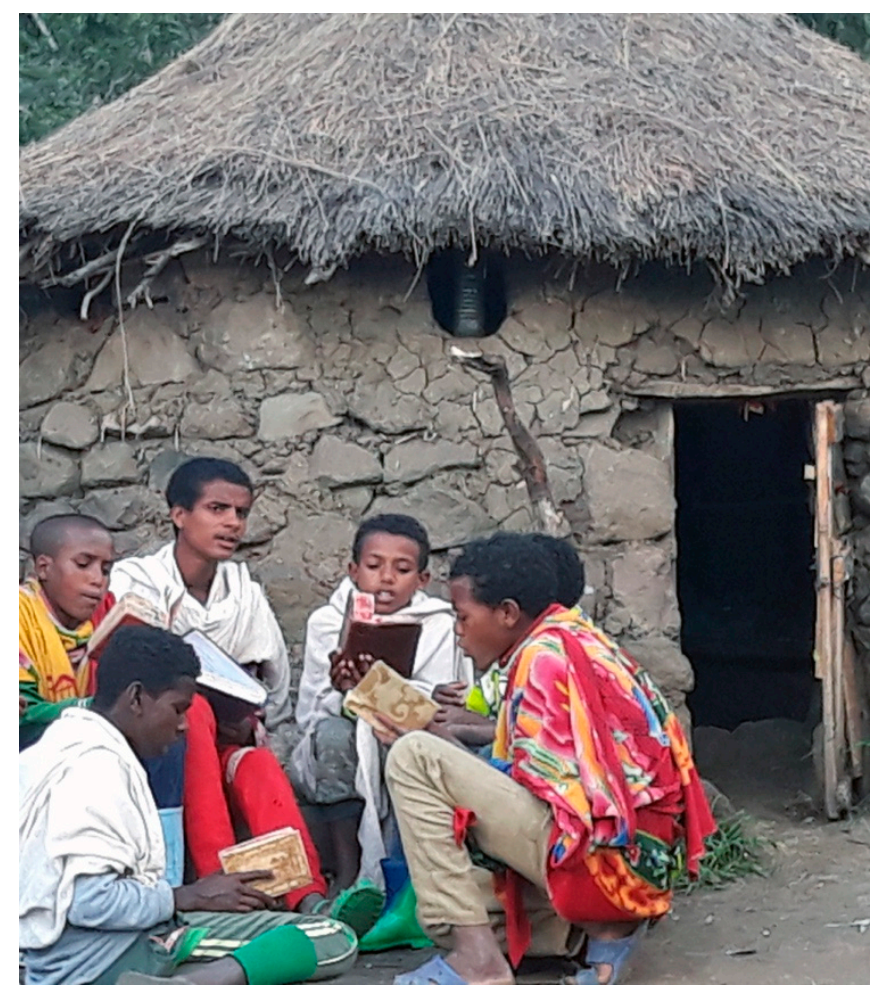

Figure 13. Backyard classes in Lalibela in 2019 (Photograph by Yirga Gelaw Woldeyes 2019).

While it is important to note how this spiritual genealogy is enduring, it is just as important to acknowledge and address how it is under threat. The major difficulty for the local people is the larger system of how heritage management and tourism operates around them. While they pass their knowledge onto the next generation, the local administration requires tourist guides to gain 
certification only from tourism institutions in Addis Ababa that train based on western standards. Local scholars, despite their decades of study and experience serving in the churches, are not regarded as having qualification for tourism. As discussed previously, this is an example of native colonialism and epistemic violence, where foreign knowledge is privileged over local knowledge and serving tourists is more profitable than serving the public at the churches. In order for Lalibela's ancient heritage to be maintained, stories like The Acts of Lalibela, and the local people and scholars who live by their word, must be centred.

Funding: This research received no external funding.

Conflicts of Interest: The author declares no conflict of interest.

\section{References}

Aalund, Flemming. 1985. Restricted Technical Report RP/1984-1985/XI.I.4. Ethiopia. Operational Action for the Safeguarding of the Immovable Cultural Heritage and Its Reintegration into Modern Life. Master Plan for the Preservation and Presentation of Cultural Heritage. Paris: UNESCO.

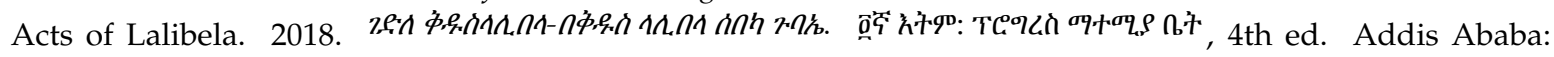
Progress Printing House, 2010 Eth. C.

Alvarez, Francisco. 1881. Narrative of the Portugeous Embassy ot Abyssinia during the Years 1520-1527. Translated by Lord Stanley. London: London Hakluyt Society.

Ayalew, Kidanemariam. 2016. Heritage Management on the Ground: Heritage Managment Versus Local Community in Lalibela (Ethiopia)? Paris: Master Erasmus Mundus TPTI.

Basso, Keith H. 1996. Wisdom Sits in Places: Landscape and Language among the Western Apache. Aluquerque: University of New Mexico Press.

Buxton, David. 1970. The Abyssinians. Southampton: Thames \& Hudson.

Chojnacki, Stanislaw. 1964. Short Introduction to Ethiopian Traditional Painting. Journal of Ethiopian Studies 2: 1-11. Available online: http://www.jstor.org/stable/41965709 (accessed on 1 September 2019).

Clement, Vincent. 2017. Beyond the sham of the emancipatory Enlightenment: Rethinking the relationship of Indigenous epistemologies, knowledges, and geography through decolonizing paths. Progress in Human Geography, 1-9. [CrossRef]

Deloria, Vine. 2003. God Is Red: A Native View of Religion. Golden: Fulcrum Publishing.

ESTDP. 2009. Ethiopian Sustainable Tourism Development Project: Resettlement Policy Framework (Final). Addis Ababa: Federal Ministry of Culture and Tourism.

Flanagan, Jane. 2018. Aid did more harm than good to Ethiopia's World Heritage churches. The Times. Available online: https://www.thetimes.co.uk/article/aid-did-more-harm-than-good-to-ethiopia-s-world-heritagechurches-8rvg0kp2t (accessed on 10 December 2018).

Hancock, Graham. 1992. The Sign and the Seal: The Quest for the Lost Ark of the Covenant. New York: Crown.

Human Rights Watch. 2012. Ethiopia: Forced Relocations Bring Hunger, Hardship. Donor Funds Should Not Facilitate Abuse of Indigenous Groups. Available online: https://www.hrw.org/news/2012/01/16/ethiopia-forcedrelocations-bring-hunger-hardship (accessed on 10 September 2019).

IMF. 1967. Lalibela—Phase I: Adventure in Restoration. New York: Internatioal Fund for Monuments.

Isaac, Ephraim. 1971. Social structure of the Ethiopian church. Ethiopian Observer 14: 240-88.

Isaac, Ephraim. 2013. The Ethiopian Orthodox Tewahido Church. Trenton: Red Sea Press.

Jahn, Janheinz. 1961. Muntu: An Outline of the New African Culture. New York: Grove.

Kalewolde, Enbaqoum. 1965. Collection of Sources for the Study of Ethiopian Culture: Documents on Traditional Ethiopian Education (in Amharic). Addis Ababa: Institute of Ethiopian Studies.

Kaplan, Steven. 1984. The Monastic Holy Man and the Christianisation of Early Solomonic Ethiopia. Wiesbaden: Franz Steiner.

Kebede, Messay. 2003. Eurocentrism and Ethiopian Historiography: Deconstructing Semitization. International Journal of Ethiopian Studies 1: 1-19.

Kebede, Messay. 2008. Radicalism and Cultural Dislocation in Ethiopia, 1960-1974. New York: University of Rochester Press.

Kebra Nagast. 1932. The Queen of Sheba and Her Only Son Menyelik I. London: Oxford University Press. 
Kirby, Terry. 2004. Hidden in a British Museum Basement: The Lost Ark Looted by Colonial Raiders. The Independent. October 19. Available online: https://www.independent.co.uk/news/uk/this-britain/hidden-in-a-britishmuseum-basement-the-lost-ark-looted-by-colonial-raiders-535318.html (accessed on 2 October 2019).

Levine, Donald N. 1974. Greater Ethiopia: The Evolution of Multiethnic Society. Chicago: The University of Chicago Press.

Levine, Donald N. 2011. Ethiopia's Nationhood Reconsidered. Análise Social 46: 311-27.

Mbiti, John S. 1969. African Religions \& Philosophy. London: Heinemann London.

McGrath, Rosita. 1925. Lalibala. The Geographical Journal 66: 507-18. [CrossRef]

Mengistu, Gobezie. 2018. The Church of Yimrhane Kristos: An Archaeological Investigation. Sweden: Lund University. Miura, Keiko. 2013. Conservation of a 'living heritage site' A contradiction in terms? A case study of Angkor World Heritage Site. Conservation and Management of Archaeological Sites 7: 3-18. [CrossRef]

MoFED. 2010. Growth and Transformation Plan (GTP) 2010/11-2014/15 [Draft]; Addis Ababa: Ministry of Finance and Economics Development.

Ndlovu-Gatsheni, Sabelo J. 2018. Epistemic Freedom in Africa: Deprovincialization and Decolonization. New York: Routledge.

Negash, Tekeste. 2003. The Zagwe Period Re-Interpreted: Post-Aksumite Ethiopian Urban Culture. Uppsala: Uppsala Universitet, The Development of Urbanism from a Global Perspective.

Negussie, Elene. 2010. Conserving the rock-hewn churches of Lalibela as a World Heritage site: A case for international support and local participation. Paper presented at Changing World, Changing Views of Heritage: Heritage and Social Change, ICOMOS Scientific Symposium, Dublin, Ireland, October 30.

Nosnitsin, Denis. 2010. Ethio-SPaRe Cultural Heritage of Christian Ethiopia: Salvation, Preservation and Research. Available online: https://www.aai.uni-hamburg.de/en/ethiostudies/research/ethiospare/missions/ pdf/report2010-1.pdf (accessed on 5 September 2019).

Pankhurst, Rita. 1990. The Maqdala Library of Tewodros. In Kasa and Kasa: Papers on the Lives, Times and Images of Tewodros II and Yohannes IV (1855-1889). Edited by Taddese Beyene, Richard Pankhurst and Shiferaw Bekele. Addis Ababa: Institute of Ethiopian Studies, Addis Ababa University, pp. 223-30.

Poulios, Ioannis. 2014. The Past in the Present: A Living Heritage Approach-Meteora. Greece: Ubiquity Press.

Rahmato, Dessalegn. 2011. Land to Investors: Large-Scale Land Transfers in Ethiopia. Addis Ababa: Forum for Social Studies.

Rahmato, Dessalegn. 2014. The Perils of Development from Above: Land Deals in Ethiopia. African Identities 12 : 26-44. [CrossRef]

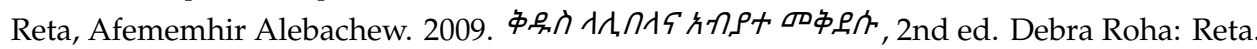

Said, Edward. 1978. Orientalism: Western Concepts of the Orient. Harmondsworth: Penguin.

Schaefer, Heinrich. 2006. Reexamining the Ethiopian Historical Record on the Continuum between Vengeance and Forgiveness. Paper presented at XVth International Conference on Ethiopian Studies, Humburg, Germany, July 20-25; Edited by Siegbert Uhlig. Wiesbaden: Harrassowitz Verlag, pp. 348-55.

Smith, Linda Tuhiwai. 2005. Decolonizing Methodologies: Research and Indigenous Peoples. London: Zed Books Ltd.

Sumner, Claude. 1981. Ethiopian Philosophy Volume IV: The Life and Maxims of Skendes. Addis Ababa: Commercial Printing Press.

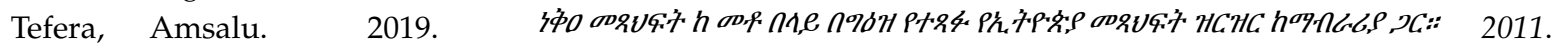
Addis Ababa: 9. 9p.

Teprin, Associati. 2010. Lalibela Ethiopia: New shelters for the five churches, entrance control and service building, Lalibela community centre. Ravenna: Danilo Montanari Editore, 2003 Et. C.

Ullendorff, Edward. 1965. The Ethiopians: An Introduction to Country and People. London: Oxford University Press.

UNESCO Website. 1978. Rock-Hewn Churches, Lalibela. Inscribed in 1978. Available online: https://whc.unesco. org/en/list/18/ (accessed on 20 August 2019).

UNESCO. 2018. Mission Report. Report of the UNESCO/ICOMOS/ICCROM Advisory Mission to Rock-Hewn Churches, Lalibela (Ethiopia). May 20-25. Available online: whc.unesco.org/document/169702 (accessed on 26 July 2019).

Wa Thiong'o, Ngugi. 1994. Decolonising the Mind: The Politics of Language in African Literature. Nairobi: East African Educational Publishers.

Watts, Vanessa. 2013. Indigenous place-thought \& agency amongst humans and non-humans (First Woman and Sky Woman go on a European world tour!). Decolonization: Indigeneity, Education and Society 2: 20-34. 
Woldeyes, Yirga Gelaw. 2017. Native Colonialism: Education and the Economy of Violence against Traditions in Ethiopia. Trenton: Red Sea Press.

Woldeyes, Yirga Gelaw. 2018a. Preliminary Report: Conservation Concerns for the Lalibela Rock Hewn Churches. Miri: Curtin University.

Woldeyes, Yirga Gelaw. 2018b. Reflections on Ethiopia's Stolen Treasures on Display in a London Museum. The Conversation. June 5. Available online: https://theconversation.com/reflections-on-ethiopias-stolentreasures-on-display-in-a-london-museum-97346 (accessed on 5 June 2018).

Woldeyes, Yirga Gelaw. 2019. Repatriation: Why Western Museums Should Return African Artefacts. The Conversation. May 15. Available online: https://theconversation.com/repatriation-why-westernmuseums-should-return-african-artefacts-117061 (accessed on 15 May 2019).

World Bank. 2006. Ethiopia in Makeda's Footsteps: Towards a Strategy for Pro-Poor Tourism Development. Washington, DC: Prepared for the Government of Ethiopia by The World Bank.

World Bank. 2008. Project Information Document (PID) Concept Stage: Ethiopia-Tourism Project (No. AB3858). Available online: http://documents.worldbank.org/curated/en/449391468031583766/ Ethiopia1PID1TDP1Concept0Stage1F11.doc (accessed on 12 December 2018).

World Bank. 2009. Project Appraisal Document on a Proposed Credit in the Amount of SDR 23.6 Millon (US\$35.00 Million Equivalent) on the Federal Democratic Republic of Ethiopia for a Ethiopia Sustainable Tourism Development Project (Report No: 47613-ET). Available online: http:/documents.worldbank.org/curated/en/ 776861468256511314/text/476130PAD0P098101Official0Use0Only1.txt (accessed on 29 November 2019).

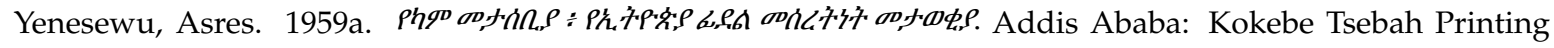
House, 1951 Eth. C.

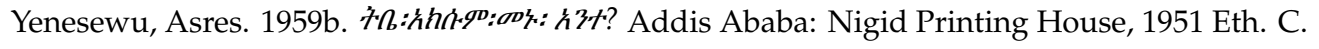

(C) 2019 by the author. Licensee MDPI, Basel, Switzerland. This article is an open access article distributed under the terms and conditions of the Creative Commons Attribution (CC BY) license (http://creativecommons.org/licenses/by/4.0/). 